\title{
The differences of work stress on teachers based on demographic factors
}

\author{
Yunita Khairani ${ }^{1}$, Marjohan ${ }^{1}$, Riska Ahmad ${ }^{1}$ \\ ${ }^{1}$ Universitas Negeri Padang \\ *Corresponding author, e-mail: yunitakhairani1@gmail.com
}

\begin{abstract}
Work stress is an emotional state that arises because of a mismatch between the workload and the individual's ability to cope with the work stress he or she faces. The stress experienced by teachers in carrying out their duties at school cannot be separated from the demands of professional duties as professional teachers, the work done must be maximal. This can be seen from the phenomenon found in the field against equivalent high school teachers in Kerinci Regency, based on an analysis of existing documents in 2019-2020, namely, there are still teachers who are late for attendance even though they have used electronic absences, and are late for teaching in class. There are also teachers who only give assignments to students in class, but the teacher remains in the office. Some teaching teachers do not use creative learning media to attract students' interest, but teach with lecture methods that seem monotonous, boring and not conducive. This study uses a quantitative approach with descriptive and comparative methods with a sample of 212 teachers selected using the Two Stage Cluster Random Sampling technique and data collection tools using a questionnaire with a Likert scale model about work stress on teachers. The results of the study revealed that teacher work stress was in the moderate category, and there is a significant difference in work stress by gender with a significance of 0.002 , a significance of age 0.049 , a significance of length of work 0.00 , and a significance of employment status 0.038 with a negligible $<0.05$. This research has implications as input for Counselors who operationally consult with school principals and jointly discuss services/activities that can help teachers to minimize stress levels experienced by teachers.
\end{abstract}

Keywords : Job Stress, Teacher, Demographic Factors

How to Cite: Khairani, Y., Marjohan, M., \& Ahmad, R. (2021). The differences of work stress on teachers based on demographic factors. International Journal of Applied Counseling and Social Sciences, 3(1): 1-8, DOI: https://doi.org/10.24036/005443ijaccs 


\section{Introduction}

Professional teachers in carrying out their duties have several obligations that must be fulfilled, namely planning learning, implementing quality learning processes, and assessing and evaluating learning outcomes (Gintings, 2010). In addition to the obligations that must be met in the learning process, teachers are also burdened with working hours that have been regulated in Permendikbud Number 15 of 2018 which is carrying out a workload of 40 hours in 1 week. The 40-hour workload consists of 37.5 hours of effective work and 2.5 hours of rest. If necessary, the school can increase the hours of rest and not reduce the effective working hours. A teacher is required to fulfill at least 12 face-to-face hours at the parent school. If you cannot fulfill 24 hours, then you can be given additional assignments which are equivalent to 12 hours or 3 different types of additional tasks which are equivalent to 6 hours face-to-face per week and add hours outside the satminkal (base administration unit) but in one zone determined by the government. service.

In fact, in carrying out the role as a professional teacher, there are not a few workloads faced by a teacher and cause complications. Some teachers have to catch up with teaching time at the main school and other schools to meet working hours. In addition, there are also teachers who carry out other tasks at school by becoming deputy heads, homeroom teachers, extracurricular coaches so that teachers have to work more extra (Purba et al, 2007). In addition to the workload, the task of the teacher as an educator is to carry out the teaching process to students every day. This can not be separated from the teacher who faces a variety of unique characters and attitudes of students. A number of teachers experience problems when carrying out learning which causes teachers to experience stressful conditions.

Handoko (2013) explains that stress is a condition in which a person experiences tension in himself which is influenced by emotions, thought processes and one's condition. Stress is pressure that occurs due to a discrepancy between the desired situation and expectations, where there is a gap between environmental demands and the individual's ability to fulfill them which is considered potentially harmful, threatening, disturbing, and uncontrollable or in other words stress is beyond the individual's ability to cope. (Barseli et al, 2017). Furthermore, Christyanti et al (2012) explained that stress is a form of interaction between individuals and the environment that is assessed by individuals as something that burdens or exceeds their abilities, and threatens welfare.

So, it can be concluded that stress is an imbalance between demands from the environment and exceeds the capabilities of the individual, which causes a depressed state both physically and psychologically. Stress is a tension that occurs from within the individual who is influenced by negative emotions caused by a mismatch between the desired situation and expectations, which causes a depressed state both physically and psychologically. The stress experienced by teachers in their work environment is called work stress

Job stress is an interaction between working conditions and the characteristics of employees who work and change normal physical, psychological and behavioral functions that come from job demands that exceed the ability of employees or environmental conditions that cause stress which can have a negative effect on employees and the organization where they work. work that requires solutions from both personal and agency (Prasetyo et al, 2018) . Furthermore, according to Vanchapo (2020) work stress is an emotional state that arises due to a mismatch between the workload and the individual's ability to cope with the work stress he faces. Job stress according to Fraser (Anoraga, 2015) arises because of a change in the 
balance of a complexity between humans, machines, and the environment. Jobs that cause stress, namely jobs that require physical conditions (work with muscles), work with skills or expertise.

The stress experienced by teachers in carrying out their duties at school cannot be separated from the demands of professional duties as professional teachers, the work done must be maximal. Moreover, teachers who meet with students every day in the learning process. Problems that come from within students, the amount of work that must be done and completed by a teacher, role conflicts, relationships with colleagues, rapid curriculum changes, and the same work routine every day, are factors that can trigger the emergence of work stress on teachers (Mangkunegara \& Puspitasari, 2015) . Factors that may affect work stress on teachers according Wahdaniyah \& Miftahuddin (2019) namely internal factors, external factors, and demographic factors. Internal factors include hardiness, job satisfaction, and saturation. External factors include workload, social support, and changes in government policies. Demographic factors include gender, years of service, age, and employment status.

In fact, the stress that occurs is a subjective reaction after the individual compares the stressful event with his abilities, so that stress occurs because someone sees the consequences of a stressful event and does not have the ability to overcome it (Hasan, 2008). The number of cases that occur and the more stressors that arise, the higher the level of stress (Taufik et al, 2013).

The job as a teacher has a significant level of stress because the teacher's job is faced with many demands, interactions at work, and unequal welfare guarantees. Teachers are faced with the demands of the curriculum or school policies which are sometimes difficult to fulfill. In addition, in their interactions with co-workers, students and parents also have the potential to cause unexpected conflicts. As for guarantees, there are honorary teachers who tend to get limited wages or private school teachers who get minimal salaries. This creates its own pressure for the profession as a teacher (Suparman, 2018) .

The phenomenon experienced by the teacher shows that there are problems from time to time. The results of a survey conducted by Anjani in 2017 stated that based on research conducted by the online community from August 2015 to January 2017, which was attended by 86,000 respondents throughout Indonesia in various types of work, several categories of work with high stress levels were found. Based on this research, the average stress level of Indonesian employees is 3.0. The survey results also revealed that public speakers, babysitters, and dental health workers had the highest stress levels. After that followed the profession as a teacher, logistics and transportation officer and telemarketing (Suparman, 2018). In addition, Li \& Zhang (2019) in their research involving 615 participants namely kindergarten teachers, completed a survey consisting of teacher work stress, psychological capital, social support, and work-related welfare questionnaires. The results show that teachers' job stress not only directly affects their work-related well-being, but their workrelated well-being is also affected through the mediating role of psychological capital.

Problems often occur in someone who is in the world of work and results in stressful conditions. Stress experienced by workers is a conflict that occurs between themselves, work and the environment. Moreover, a job whose profession is a teacher, demands that come from many angles cause internal conflicts which can then cause work stress. The amount of stressor pressure for someone experiencing stress is prone to diseases that arise as symptoms of work stress behavior. 


\section{Method}

This research is a research that uses a quantitative approach with descriptive and comparative methods. research with descriptive format is research that aims to explain, summarize conditions with various situations, or various variables that arise in society based on what they are in accordance with reality (Subana, 2010). This study will also describe the difference (comparative) of work stress on teachers based on demographic factors.

Furthermore, this study aims to describe the conditions of work stress on teachers and compare work stress based on demographic factors, namely gender, age, length of work and employment status. This research was conducted on all senior high school teachers in Kerinci Regency with a total population of 1005 people, which were divided into 597 SMA teachers, 270 SMK teachers, and 138 MAN teachers. Sampling using the Two- stage Cluster Random Sampling technique, the number of samples in this study was 212 teachers. The data collection tool uses a questionnaire with a Likert scale model, about work stress and teacher work motivation. Data were analyzed using descriptive statistical techniques, then $t$ test analysis for gender, age and employment status and Test Analysis of varianve (ANOVA) one way to test for differences in long work on teachers

\section{Results and Discussion}

\section{Overview of Job Stress on Teachers}

The results of data collection and processing through work stress instruments from a total sample of 212 teachers, can be seen in the following table:

Table 1. Level of achievement of respondents' work stress

\begin{tabular}{cccc}
\hline Category & Score & F & $\%$ \\
\hline ST & $\geq 144$ & 0 & 0 \\
T & $\geq 125 \mathrm{~s} / \mathrm{d}<144$ & 66 & 31,1 \\
S & $\geq 107 \mathrm{~s} / \mathrm{d}<125$ & 76 & 35,8 \\
$\mathbf{R}$ & $\geq 89 \mathrm{~s} / \mathrm{d}<107$ & 47 & 22,2 \\
SR & $<89$ & 23 & 10,8 \\
\hline
\end{tabular}

Based on the results of descriptive data processing, it was found that the overall level of achievement of respondents' work stress data for high school teachers in Kerinci Regency showed the figure of $35.8 \%$ with a frequency of 76 being in the medium category.

The low level of work stress for teachers in senior high schools in Kerinci Regency at least minimizes the risk of stress impacting the quality of education in Kerinci. If work stress on teachers is not managed properly it will affect the quality of education. Teachers who experience stress in their work can trigger various other problems that come from themselves and have an impact on work, the environment and the people around them (Mangkunegara \& Puspitasari, 2015) .

The job as a teacher is not an easy job because it requires special skills. The teacher's job is not only to deliver material to students in front of the class, but also to prepare and design teaching materials, assess learning processes and outcomes, and shape the character and character of students. A teacher is required to be professional with all the demands and 
workloads that have been set. Professional demands and great demands from the community, as well as the lack of welfare achieved make the teacher depressed and potentially cause stress.

Stress on teachers can happen at any time, not only teachers who are less able to achieve the demands of the work that have been set, but even perfectionist teachers can experience stressful conditions. This can happen if the perfectionist attitude is always carried out and makes the teacher feel bored and the environment is not supportive.

\section{Job Stress on Teachers based on Demographic Factors}

Demographic factors are one of the factors that can affect the work stress conditions for teachers. According to Wahdaniyah \& Miftahuddin (2019), the demographic factors that can affect work stress are: (1) gender, namely male and female; (2) working period according to Suma'mur, (2009) namely, working period of 1 year - 8 years, working period of 9 years - 16 years, working period of 17-24 years, working period of 25 years - 33 years; (3) age, namely a period of adults 18-40 years old and middle age 41-60 years; (4) categorization of employment status is generally categorized into PNS teachers and non-PNS teachers .

The results of data collection and processing through work stress instruments based on demographic factors can be seen in the following table.

Table 2. Work stress based on demographic factors

\begin{tabular}{cccccc}
\hline $\begin{array}{c}\text { Demographic } \\
\text { Factors }\end{array}$ & Grouping & N & Mean & $\begin{array}{c}\text { Std. } \\
\text { Deviation }\end{array}$ & Category \\
\hline Gender & Man & 88 & 109.6932 & 14.93692 & $\mathrm{~S}$ \\
\cline { 2 - 6 } & Woman & 124 & 116.6371 & 16.70905 & $\mathrm{~T}$ \\
\hline Age & $18-40$ years old & 113 & 115.8230 & 16.71143 & $\mathrm{~T}$ \\
\cline { 2 - 6 } & $41-60$ years & 99 & 111.3939 & 15.62299 & $\mathrm{~S}$ \\
\hline \multirow{2}{*}{$\begin{array}{c}\text { Employment } \\
\text { status }\end{array}$} & $\begin{array}{c}\text { civil servant } \\
\text { Non civil } \\
\text { servant }\end{array}$ & 149 & 115.2617 & 16.32665 & $\mathrm{~T}$ \\
\cline { 2 - 6 } & & 110.1905 & 15.88452 & $\mathrm{~S}$ \\
\hline
\end{tabular}

Work stress experienced by teachers who ari female. This is based on the average obtained by female teachers is higher than male teachers' stress. The results of this study are in line with the opinion of Khilmiyah (2017) which explains that the career process for female teachers is more complex than male teachers due to differences in socialization and the combination of attitudes, role expectations, behavior, and sanctions related to female teacher career process. Various roles ( multiple roles) for female teachers to be a factor that can influence the careers of women.

The world of work and family life are two very important things and influence each other. A woman who chooses to pursue a career is not easy considering the work to be done related to the household. Female teachers can become stressed if the work done at home and at school is overloaded and monotonous every day. Moreover, if there are problems in the family or school problems that result in the physical and psychological condition of the teacher. Female teachers who are more emotionally involved than men are less able to think rationally like men will make the teacher depressed to experience stress.

Work stress tends to be experienced by teachers aged 18 to 40 years. Based on the average obtained, the stress of teachers aged 18 to 40 is higher than the stress of teachers aged 41 to 60 
years. This is because those aged 41 to 60 years or older tend to be more mature and able to manage their stress than younger workers with an age range of 41 to 60 years (Kamal, 2015) .

The increasing age of a person will reduce the level of work stress. This is because the defense system in older teachers is very good. Because the older a person is, the greater the level of his defense against pressure in the work environment. In addition, young people are prone to stress because they are less able to control their emotions and the ability to solve problems is also minimal. Teachers who are 18-40 years old on average are just starting a career so they are not too fluent in their work and family life and other environments are also triggers for stress on the teacher.

Work stress tends to be experienced by teachers with civil servant status. . Based on the average obtained, the stress of civil servant teachers is higher than the stress of non civil servant teachers. This is in line with Pertiwi \& Wardan's research (2019) which states that non civil servant teachers experience a higher stress level than civil servant teachers, which is $8.1 \%$. The factor that causes work stress experienced by non civil servant teachers is the dissatisfaction of the non- civil servant teachers with the salary they receive. Income / salary contribute to triggering work stress (Eria, 2013) .

Many things can trigger stress in non civil servant teachers. Non civil servant teachers who work in schools in general have tasks that are not much different from civil servant teachers, but the income of non civil servant teachers is sometimes as uncertain as that of civil servant teachers. With the many necessities of life and the salary earned can cause the teacher to feel stressed.

The results of data collection and processing through work stress instruments based on long working factors can be seen in the following graph.

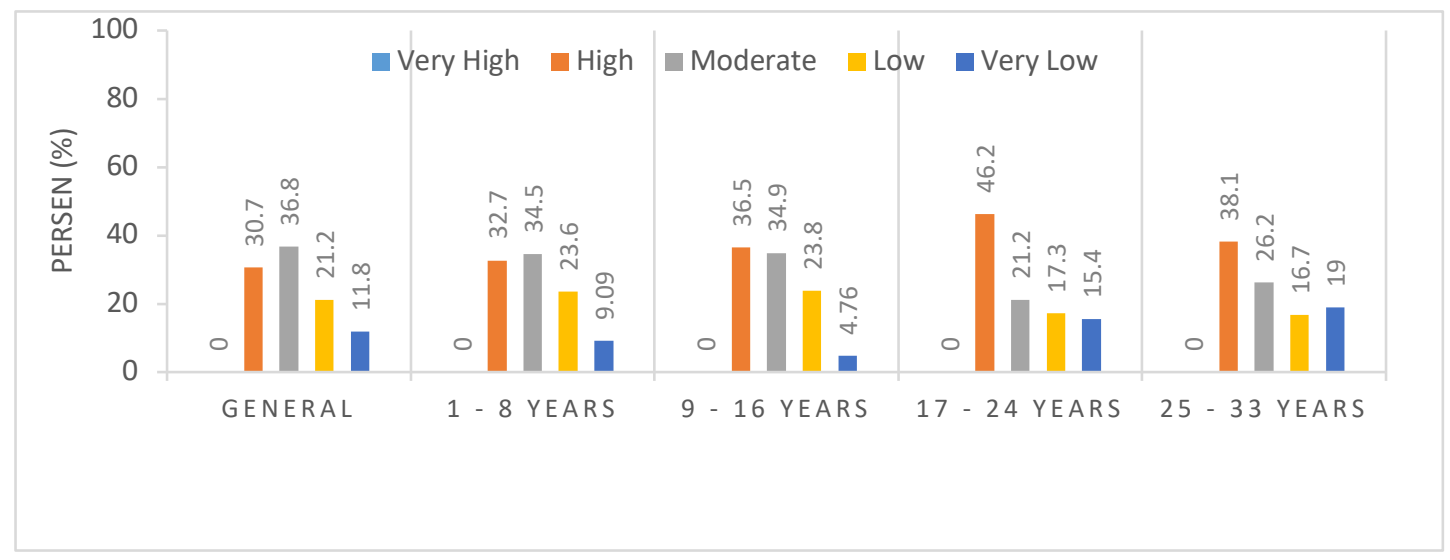

Based on the results of the study showed that teachers with a length of work 9 to 16 years, 17 to 24 years and 25 to 33 years experienced high stress. The research result of the show in general teachers who work often experience the stress of work with vulnerable conditions of teachers who feel bored in work and daily life.

$S$ tudi conducted by Frone about job stress states that the longer service life of the stress experienced person will be even greater, along with a rise office and increased the magnitude of one's responsibilities. Workers with longer tenures tend to have more complicated and many problems compared to workers with fewer tenures so they will have higher stress levels (Fathonah \& Renhoran, 2021). Furthermore, Ferlia et al, (2016) explained that the working periode approaching retirement can also be a source of stress for teachers because 
they feel depressed because they are worried about work after retirement and sources of income, depressed because they think about sources of income to meet the needs of daily life.

Problems that occur in teachers who have long pursued a career as a teacher make it easier for teachers to experience stress. The longer a person works, the more changing patterns and demands imposed by the government. As with technology, the longer it gets, the more sophisticated it will be so that it will require teachers to adapt and have new knowledge all the time. This becomes an obstacle for teachers who have worked for a long time because such as curriculum changes can also change the pattern of teaching planning. This can trigger work stress on teachers who have worked for a long time. Meanwhile, for teachers who have just worked, on average, they are able to master technology and have worn out knowledge so that they can reduce stress levels.

\section{Conclusion}

Based on the findings obtained, it is concluded that the average job stress on teachers is in the medium category. The results of this study mean that in general, teachers in high school equivalents in Kerinci Regency experience stressful conditions. Teachers who experience stress in their work can trigger various other problems that come from themselves and have an impact on work, the environment and people around them .

Furthermore, there are significant differences in work stress conditions for teachers in senior high schools in Kerinci Regency based on demographic factors, which: (1) based on gender, work stress tends to be experienced by female teachers than male teachers; (2) by age, teachers aged 41 to 60 experience higher levels of job stress than teachers aged 18 to 40; (3) based on employment status, civil servant teachers experience more stress than non-civil servant teachers; and (4) based on the length of work, the results of the study show that teachers with a length of service of 9 to 16 years, 17 to 24 years, and 25 to 33 years are higher than the work stress of teachers who have worked for 1 to 8 years.

Therefore, it is necessary to follow up to reduce the level of stress experienced by teachers. Operationally, the BK Teacher/Counselor consults with the principal regarding these findings and discusses together with the principal and vice principal of appropriate services/activities in helping teachers to increase motivation and minimize stress levels experienced.

The results of this study can be a contribution of thought in the scientific repertoire regarding differences in work stress on teachers based on demographic factors, as well as their implications for guidance and counseling services and can enrich theory to be used as a basis / reference material in further research on work stress on teachers.

\section{References}

Anoraga, P. (2015). Psikologi Kerja. Jakarta: Rineka Cipta.

Christyanti, D., Mustami'ah, D., \& Sulistiani, W. (2012). Hubungan antara penyesuaian diri terhadap tuntutan akademik dengan kecenderungan stres pada mahasiswa Fakultas Kedokteran Universitas Hang Tuah Surabaya. Jurnal Insan Media Psikologi, 12(3).

Eria, E. (2013). Peranan Tingkat Penghasilan Dalam Meningkatkan Kinerja Guru MTS Swasta. Ekonomi IKIP Veteran Semarang, 1(2), 37056.

Fathonah, S., \& Renhoran, C. R. (2021). Gambaran Tingkat Stress Guru Madrasah Aliyah Di 
Jakarta Selatan Selama Masa Pandemi. Jurnal Pendidikan Islam, 12(1), 57-71.

Ferlia, D. A., Jayanti, S., \& Suroto, S. (2016). Analisis Tingkat Stres Kerja Pada Guru Tuna Grahita Di Sekolah Dasar Luar Biasa (Sdlb) Negeri Purwosari Kudus. Jurnal Kesehatan Masyarakat (Undip), 4(3), 331-341.

Gintings, A. (2010). Esensi Praktis Belajar \& Pembelajaran; Disiapkan untuk Pendidikan Profesi dan Sertifikasi Guru-Dosen. Bandung: Humaniora Utama Press

Handoko, T. H. (2013). Manajamen Personalia dan Sumber Daya Manusia. Yogyakarta: BPFE. Hasan, A. B. (2008). Pengantar Psikologi Kesehatan Islami. Jakarta: Raja Grafindo Persada.

Kamal, M. A. (2015). Hubungan Bising Subyektif Dengan Persepsi Stres Pekerja Menggunakan Skor Skala Persepsi Stres Serta Faktor-Faktor Lain Pada Pekerja PT K. Jakarta

Khilmiyah, A. (2017). Stres kerja guru perempuan di kecamatan kasihan bantul yogyakarta. Lentera Pendidikan: Jurnal Ilmu Tarbiyah Dan Keguruan, 15(2), 135-143.

Li, Y., \& Zhang, R.-C. (2019). Kindergarten teachers' work stress and work-related well-being: A moderated mediation model. Social Behavior and Personality: An International Journal, 47(11), 1-11.

Luma, M. (2018). Hubungan Lingkungan Kerja dengan Stres Kerja Guru di SDN SeKecamatan Batudaa Kabupaten Gorontalo. Jurnal Ilmiah Iqra', 10(1).

Mangkunegara, A. A. A. P., \& Puspitasari, M. (2015). Kecerdasan emosi guru, stres kerja, dan kinerja guru SMA. Jurnal Kependidikan: Penelitian Inovasi Pembelajaran, 45(2).

Pertiwi, N. Y., \& Wardani, I. Y. (2019). ingkat Stres Kerja dan Strategi Koping Guru SD dalam Implementasi Kurikulum 2013. Jurnal Ilmiah Permas: Jurnal Ilmiah STIKES Kendal, 9(2), 155-164.

Prasetyo, A. Y., Fathoni, A., \& Malik, D. (2018). Analisis Pengaruh Konflik Keluarga-Pekerjaan, Hardiness, Self Efficacy terhadap Stress Kerja dengan Dukungan Sosial sebagai Variabel Moderasinya (Studi pada Guru Demak). Journal of Management, 4(4).

Purba, J., Yulianto, A., Widyanti, E., Esa, D., \& Esa, M. (2007). Pengaruh dukungan sosial terhadap burnout pada guru. Jurnal Psikologi, 5(1), 77-87.

Sandra, R., \& Ifdil, I. (2015). Konsep Stres Kerja Guru Bimbingan dan Konseling. Jurnal EDUCATIO: Jurnal Pendidikan Indonesia, 1(1), 80-85.

Subana, M. (2010). Dasar-Dasar Penelitian Ilmiah. Bandung: Pustaka Setia.

Suma'mur, P. K. (2009). Corporate Hygiene and Occupational Health. Jakarta: Sagung Seto.

Suparman. (2018). Identifikasi Gejala Stres pada Guru Tingkat Sekolah Dasar di Sekolah Lentera Harapan Tangerang. Jurnal Pendidikan Dompet Dhuafa, 8, 1.

Taufik, T., Ifdil, I., \& Ardi, Z. (2013). Kondisi Stres Akademik Siswa SMA Negeri di Kota Padang. Jurnal Konseling Dan Pendidikan, 1(2), 143-150.

Vanchapo, A. R. (2020). Beban Kerja dan Stres Kerja. Surabaya: Qiara Media.

Wahdaniyah, N., \& Miftahuddin, M. (2019). Pengaruh Hardiness, Beban Kerja, dan Faktor Demografi Terhadap Stres Kerja Guru. Tazkiya Journal of Psychology, 6(1). 